\title{
Effect of different levels of faba bean in diets on growth performance of young pigs*
}

\author{
M. Kasprowicz ${ }^{1}$, A. Frankiewicz and M. Urbaniak \\ The August Cieszkowski Agricultural University of Poznań, \\ Department of Animal Nutrition and Feed Management \\ Wotyńska 33, 60-637 Poznań, Poland
}

\begin{abstract}
Forty crossbred pigs of an initial body weight of about $14 \mathrm{~kg}$ were divided into 4 groups and placed in individual pens. The control animals (group K) were fed ad libitum a mixture containing soyabean meal (SBM), whereas in the case of diets fed to experimental groups, $25 \%$ (group 1), 50\% (group 2) and $75 \%$ (group 3) of the soya protein was replaced by the protein of faba bean cv. Kodam. Diets were balanced on the basis of apparent ileal amino acid digestibility. The experiment ended when the animals reached a body weight of $36 \mathrm{~kg}$. The average daily gain (ADG) of animals from the control group was $586 \mathrm{~g}$, the feed:gain ratio $(\mathrm{F} / \mathrm{G})$ was $2.59 \mathrm{~kg}$. In the experimental groups, the ADG was: $577 \mathrm{~g}$ (group 1), $629 \mathrm{~g}$ (group 2) and $637 \mathrm{~g}$ (group 3) and F/G was: 2.35, 2.28 and $2.17 \mathrm{~kg} /$ $\mathrm{kg}$, respectively. In comparison with the control group, the feed conversion ratio was significantly better $(\mathrm{P}<0.05)$ in groups 2 and 3 than in groups $\mathrm{K}$ and 1 .
\end{abstract}

KEY WORDS: faba bean, pigs, growth performance

\section{INTRODUCTION}

Attempts to replace post-extraction soyabean meal (SBM) in mixtures for pigs by cheaper domestic feeds have been going on for years. Faba bean cv. Kodam is a new cultivar registered recently and is characterized by good agrotechnical (high seed and protein yields per ha) and nutritional (high protein and lysine, low fibre content) properties in comparison with other modern cultivars of this feedstuff. However, seeds of the Kodam cv. contain considerable quantities of tannins and, when compared with soyabean meal, are characterized by significantly lower apparent ileal digestibility of amino acids, except arginine and proline. In addition, the content and digestibility of methionine is particularly low, which poses a real danger of a considerable deficit of this amino acid (Kasprowicz and Frankiewicz, 2003a,b; 2004).

\footnotetext{
* Supported by the State Committee for Scientific Research, Grant No. 6 P06E 02920

${ }^{1}$ Corresponding author: e-mail: malgokas@poczta.onet.pl
} 
Formulation of pig diets containing faba bean seeds cv. Kodam as a substitute for SBM basing on apparent ileal amino acid digestibility and supplementation with crystalline amino acids should improve nutritional efficiency of the diets and allow obtaining results similar to those observed when growing pigs are fed an SBM diet.

The objective of the performed investigations was to determine the effect of inclusion of various levels of faba bean seeds cv. Kodam, as a substitute for soyabean meal in diets, on body weight gain and feed utilization by young pigs.

\section{MATERIAL AND METHODS}

The experimental animals comprised 40 crossbred pigs initially of $14 \mathrm{~kg}$ body weight divided into 4 groups of 10 animals each and placed in individual pens. The control animals (group K) were fed ad libitum a standard diet containing soyabean meal, whereas animals from the experimental groups 1,2 and 3 were fed diets in which 25,50 and $75 \%$ of the SBM protein was replaced by the protein of faba bean $\mathrm{cv}$. Kodam, respectively. The dry matter of faba bean seeds contained: $29.5 \%$ crude protein, $7.2 \mathrm{mg} / \mathrm{g}$ tannins, while $100 \mathrm{~g}$ protein contained $6.00 \mathrm{~g}$ lysine, 0.74 $\mathrm{g}$ methionine and $3.53 \mathrm{~g}$ threonine (Kasprowicz and Frankiewicz, 2003a,b). Diets (Table 1) were formulated on the basis of apparent ileal digestible amino acid content according to NRC (1998) recommendations (own data). For faba bean and SBM, apparent ileal digestibility coefficients were: lysine 76.4 and $87.1 \%$,

Table 1. Feed components and chemical composition of mixtures, $\%$

\begin{tabular}{lcrrr}
\hline Item & $\mathrm{K}$ & 1 & 2 & \multicolumn{1}{c}{3} \\
\hline Maize meal & 15.00 & 15.00 & 15.00 & 15.00 \\
Wheat meal & 55.40 & 49.38 & 43.06 & 37.44 \\
Soyabean meal & 25.00 & 20.50 & 16.00 & 11.60 \\
Faba bean meal & - & 10.20 & 21.00 & 31.00 \\
Soya oil & 1.10 & 1.50 & 1.50 & 1.50 \\
Calcium phosphate & 0.50 & 0.50 & 0.50 & 0.50 \\
Acidifier & 0.30 & 0.30 & 0.30 & 0.30 \\
Limestone & 1.50 & 1.50 & 1.50 & 1.50 \\
L-Lysine & 0.30 & 0.20 & 0.20 & 0.15 \\
DL-Methionine & - & 0.02 & 0.04 & 0.06 \\
Premix & 0.40 & 0.40 & 0.40 & 0.40 \\
NaCl & 0.50 & 0.50 & 0.50 & 0.50 \\
Metabolizable energy* & 13.55 & 13.56 & 13.47 & 13.37 \\
Crude protein & 18.38 & 18.30 & 18.38 & 18.37 \\
Digestible lysine* & 0.81 & 0.77 & 0.79 & 0.77 \\
Digestible methionine* & 0.22 & 0.21 & 0.20 & 0.20 \\
Digestible threonine* & 0.47 & 0.46 & 0.46 & 0.45 \\
\hline
\end{tabular}

* calculated amounts 
methionine 53.8 and $87.3 \%$, and threonine 68.7 and $82.0 \%$, respectively (Kasprowicz and Frankiewicz, 2004). The experiment was carried out until the animals reached a body weight of about $36 \mathrm{~kg}$ and included the control of body weight gain and feed consumption. The results were subjected to statistical analysis of variance and the significance of differences between groups was calculated by Duncan's test (STATGRAPHICS program).

\section{RESULTS}

The average daily gain (ADG) in the control group reached $586 \mathrm{~g}$, while in the experimental groups the gains increased as the percentage of faba bean seeds in the diets increased; in groups 2 and 3, they exceeded the values of the control group by 7.3 and $8.8 \%$, respectively (Table 2 ). The observed differences were not confirmed statistically $(\mathrm{P}>0.05)$. The feed:gain ratio $(\mathrm{F} / \mathrm{G})$ was $2.59 \mathrm{~kg}$ in the control group, whereas in the experimental groups, it was lower by $9.3(\mathrm{P}>0.05)$, 12 , and $16.2 \%(\mathrm{P}<0.05)$.

Table 2. Body weight, average daily gain (ADG) and feed:gain (F/G) ratio

\begin{tabular}{lcccc}
\hline Item & $\mathrm{K}$ & 1 & 2 & 3 \\
\hline Initial body weight, $\mathrm{kg}$ & $14.2 \pm 2.1$ & $14.1 \pm 1.7$ & $14.2 \pm 2.0$ & $14.2 \pm 1.2$ \\
Final body weight, $\mathrm{kg}$ & $36.7 \pm 1.0$ & $36.5 \pm 0.8$ & $36.9 \pm 0.6$ & $36.4 \pm 1.4$ \\
& & & & \\
$\mathrm{ADG}, \mathrm{g}$ & $586 \pm 28$ & $577 \pm 16$ & $629 \pm 27$ & $637 \pm 40$ \\
$\%$ & 100.00 & 98.52 & 107.29 & 108.76 \\
$\mathrm{~F} / \mathrm{G}, \mathrm{kg} / \mathrm{kg}$ & $2.59 \pm 0.12$ & $2.35 \pm 0.06$ & $2.28 \pm 0.05$ & $2.17 \pm 0.09$ \\
$\%$ & $100.00^{\mathrm{a}}$ & $90.73^{\mathrm{ab}}$ & $88.03^{\mathrm{b}}$ & $83.78^{\mathrm{b}}$ \\
\hline
\end{tabular}

a,b - means in the rows with different letters differ significantly at $\mathrm{P}<0.05$

\section{DISCUSSION}

The replacement of up to $75 \%$ of SBM protein by faba bean protein did not deteriorate the growth performance of young pigs. The significantly better F/G in the groups fed the highest proportion of faba bean (groups 2,3) can probably be attributed to adequate diet composition based on the content of digestible amino acids. As was demonstrated in our earlier studies (Kasprowicz and Frankiewicz, 2003a, 2004), faba bean seeds cv. Kodam, in comparison with SBM, are characterized not only by a significantly lower methionine content, but also by its lower digestibility in the pig small intestine, which confirms the observations of Sauer et al. (2001). Another cause of the obtained results could be attributed to the fact that the SBM used in digestibility trials and in the growth experiment derived from different batches and could, therefore, be characterized by somewhat worse protein 
quality and amino acid digestibility. It is probable that the high amount of tannins in faba bean seeds cv. Kodam, $7.2 \mathrm{mg} / \mathrm{g}$, did not have a negative effect on the growth performance of young pigs, which is in agreement with results obtained by Flis et al. (1999) and Grala et al. (1993).

\section{CONCLUSIONS}

Our results indicate that faba bean cv. Kodam can replace up to $75 \%$ of soyabean protein in diets for young pigs, formulated on the basis of ileal digestible amino acid content and supplemented according to pig requirements with crystalline amino acids.

\section{REFERENCES}

Flis M., Sobotka W., Purwin C., Zduńczyk Z., 1999. Nutritional value of diets containing field bean seeds with high or low proanthocyanidin levels for pig. J. Anim Feed Sci. 8, 171-180

Grala W., Jansman A., van Leeuwen P., Huisman J., van Kempen G., Verstegen M., 1993. Nutritional value of faba beans fed to young pigs. J. Anim. Feed Sci. 2, 169-179

Kasprowicz M., Frankiewicz A., 2003a. The chemical composition of several varieties of faba bean and pea seeds. Pol. J. Nat. Sci. 14, 369-373

Kasprowicz M., Frankiewicz A., 2003b. The content of some antinutritional factors in new varieties of faba bean and pea seeds. Pol. J. Nat. Sci. 14, 375-381

Kasprowicz M., Frankiewicz M., 2004. Apparent and standardized ileal digestibility of protein and amino acids of some new varieties of faba bean and pea seeds in growing pigs. J. Anim. Feed Sci. 13, 463-473

NRC, 1998. Nutrient Requirements of Swine. $10^{\text {th }}$ Edition. Natl. Academy Press. Washington, DC

Sauer W., He J., Fan M., Cervantes M., Kies A., Caine W., 2001. Variability of amino acid digestibility in pigs: inherent factors in feedstuffs and consideration in methodology. J. Anim. Feed. Sci. 10, Suppl. 1, 115-138

\section{STRESZCZENIE}

\section{Wpływ różnych poziomów bobiku w mieszankach na wyniki odchowu świń}

40 warchlaków mieszańców o początkowej masie ciała około $14 \mathrm{~kg}$ przydzielono do 4 grup i umieszczono w indywidualnych kojcach. Zwierzęta kontrolne (grupa K) żywiono ad libitum mieszanką z udziałem poekstrakcyjnej śruty sojowej (SBM), a w mieszankach dla grup doświadczalnych zastąpiono odpowiednio 25\% (grupa 1), 50\% (grupa 2) lub 75\% (grupa 3) białka SBM białkiem bobiku odmiany Kodam. Mieszanki przygotowano uwzględniając pozorną jelitową strawność aminokwasów. Doświadczenie zakończono po uzyskaniu przez zwierzęta $36 \mathrm{~kg}$ m.c. Świnie grupy kontrolnej przyrastały średnio po 586 g dziennie zużywając na przyrost $1 \mathrm{~kg}$ masy ciała 2,59 paszy. Dzienny przyrost w grupach doświadczalnych wynosił średnio 577 (grupa 1), 629 (grupa 2) oraz $637 \mathrm{~g}$ (grupa 3), a zużycie paszy na przyrost $1 \mathrm{~kg}$ m.c. odpowiednio 2,35; 2,28 i 2,17 $\mathrm{kg}$. Wykorzystanie paszy w grupach 2 i 3 było istotnie lepsze $(\mathrm{P}<0,05)$ niż w grupie kontrolnej. 